\title{
Evaluating the cost and clinical effectiveness of long-acting, injectable aripiprazole and paliperidone palmitate once a month in a real-world setting [Corrigendum]
}

Hodgson RE. Clinicoecon Outcomes Res. 2019;11:517-524.

On page 523, "Acknowledgments" and "Disclosure" sections should read as follows:

\section{Acknowledgments}

The author would like to thank C Aladakatti, B Davenport, and T Saravanappa for their assistance with data collection and A Kinmond for help with manuscript revision. Dr Hodgson has received lecture fees and educational support from Janssen, Lundbeck and Otsuka. Lundbeck has provided financial support for medical writing assistance provided by David Whitford and HAVAS Just. Lundbeck had no influence or input in this service evaluation and submission of manuscript.

\section{Disclosure}

The author reports no conflicts of interest in this work.

Following a review of the funding statement in the "Acknowledgments" section post-publication, "unrestricted educational grant" was mistakenly used. The author apologies for this oversight.

\section{Publish your work in this journal}

ClinicoEconomics and Outcomes Research is an international, peerreviewed open-access journal focusing on Health Technology Assessment, Pharmacoeconomics and Outcomes Research in the areas of diagnosis, medical devices, and clinical, surgical and pharmacological intervention. The economic impact of health policy and health systems organization also constitute important areas of coverage. The manuscript management system is completely online and includes a very quick and fair peer-review system, which is all easy to use. Visit http://www.dovepress.com/testimonials.php to read real quotes from published authors. 